\title{
Pelatihan Kurikulum 2013 Edisi Revisi 2018 bagi Guru di Yayasan Pendidikan Islam Al-Maunah
}

\author{
Nuryana ${ }^{1}$, Dede Cahyati Sahrir ${ }^{2}$ \\ 1,2 IAIN Syekh Nurjati Cirebon, Indonesia
}

\begin{abstract}
A B S T R A C T
CURRICULUM TRAINING 2013 REVISION EDITION 2018 FOR TEACHERS IN ISLAMIC EDUCATION FOUNDATIONS AL-MAUNAH. The revised curriculum edition 2013 is still not fully understood by teachers both in terms of the principle and its application. Teachers at MTs and MA Al-Maunah also felt this way. Neither the ministry of religion nor the school had involved teachers in the Curriculum 2013technical guidance. The method used in this service was through an active learning approach with multiple implementation strategies. Community service activities are carried out in five stages, namely: 1 ) exploration of the problems of assisted subjects; 2 ) workshop; 3) practice of preparing learning plans and peer teaching; 4) reel teaching in class; and 5) evaluation. The training and mentoring effort was able to change the mindset of the revised edition of the Curriculum 2013 among teachers. Teachers began to have self-awareness of the shortcomings they had been doing in learning and felt they better understood how to apply the revised edition of the Curriculum 2013.

Keywords: Curriculum 2013, Curriculum 2013 Revised Edition, Teachers, Training.

\begin{tabular}{llll}
\hline Received: & Revised: & Accepted: & Available online: \\
05.10 .2019 & 16.12 .2019 & 03.02 .2020 & 14.02 .2020 \\
\hline
\end{tabular}
\end{abstract}

\section{Suggested citation:}

Nuryana., \& Sahrir, D. (2020). Pelatihan kurikulum 2013 edisi revisi 2018 bagi guru di yayasan pendidikan Islam Al-Maunah. Jurnal Pengabdian Pada Masyarakat, 5(1), 1-10. https://doi.org/10.30653/002.202051.259

Open Access I URL: http://ppm.ejournal.id/index.php/pengabdian/article/view/259

2 Corresponding Author: Jurusan Tadris Biologi, IAIN Syekh Nurjati Cirebon; Jl. Perjuangan By Pass Sunyaragi, Kesambi, Kota Cirebon, Jawa Barat; Email: dedecahyati@syekhnurjati.ac.id 


\section{PENDAHULUAN}

Kurikulum dirancang untuk dapat memaksimalkan potensi dari peserta didik. Kegiatan pembelajaran yang mengacu pada suatu kurikulum tertentu diharapkan dapat mengelaborasi keseluruhan potensi peserta didik yang terhimpun dalam jasmani maupun rohaninya (Kusumaningrum, Arifin, \& Gunawan, 2017). Kementerian Pendidikan dan Kebudayaan Republik Indonesia pada tahun 2013 menetapkan secara resmi kurikulum terbaru sebagai produk kebijakan pendidikan, yang selanjutnya disebut sebagai Kurikulum 2013. Melalui kebijakan kurikulum 2013 tersebut, besar harapan masyarakat Indonesia mampu bersaing secara unggul dalam menguasai ilmu dan teknologi sesuai yang telah digariskan oleh haluan negara (Mulyasa, 2013).

Implementasi pembelajaran berbasis kurikulum 2013 pada tataran praktis masih mengindikasikan bahwa aktivitas di dalamnya belum optimal. Hal tersebut sejalan dengan temuan penelitian Gunawan (2017) yang tertuang dalam kerangka kerja implementasi pembelajaran yang disajikan pada Gambar 1.

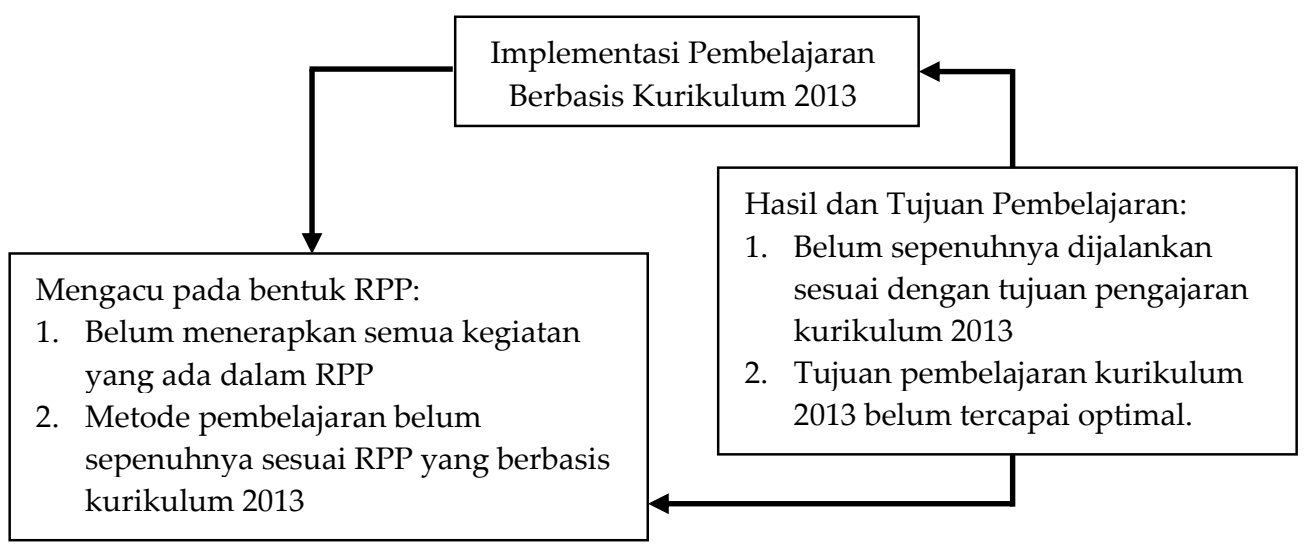

Gambar 1. Kerangka Kerja Implementasi Pembelajaran Kurikulum 2013

Terdapat dua faktor yang mempengaruhi keberhasilan dari implementasi Kurikulum 2013, yaitu: (1) faktor penentu yang mencakup guru dan buku ajar; (2) faktor pendukung yang mencakup pembinaan, pemantauan dan penguatan budaya sekolah (Widyasari \& Yaumi, 2014). Oleh karena itu perlu ada pendampingan secara berkesinambungan bagi guru untuk dapat memaknai kurikulum 2013 secara utuh sehingga mampu menjadi fasilitator yang handal dan mampu mengoptimalkan pemanfaatan buku guru/buku siswa yang telah dibuat pemerintah.

Guru bukan lagi hanya dipandang sebagai faktor pelengkap, karenanya diharapkan guru merupakan tenaga ahli yang memiliki kompetensi yang mendorong terselenggaranya pembelajaran yang berkualitas. Dalam kurikulum 2013, pembelajaran harus melibatkan siswa secara dominan agar mereka dapat bereksplorasi menemukan, membentuk dan menggali kompetensi serta kebenaran ilmiah (Prastowo, 2014; Mulyasa, 2013).

Kesiapan seorang guru meruapakan aspek penting untuk dapat mengukur sejauh mana implementasi Kurikulum 2013 dapat diterima. Sayangnya masih banyak guru yang merasa belum sepenuhnya siap untuk dapat mengintegrasikan Kurikulum 2013 dalam pembelajaran. Guru masih cenderung memprioritaskan aspek pengetahuan 
dalam menilai proses belajar siswa. Hal tersebut dapat dilihat dari teknik evaluasi dan instrumen yang digunakan merupakan instrumen tes dalam bentuk soal (Gunawan, 2017).

Berdasarkan pelaksanan studi pendahuluan berupa wawancara dengan guru-guru di MTs dan MA Al-Maunah didapatkan hasil bahwa para guru mengakui pemahaman meraka tentang Kurikulum 2013 dirasa masih sangat minim. Selama mengajar mereka masih mengembangkan proses pembelajaran sebatas pengetahuan dan pemahaman tentang kurikulum yang dimilikinya. Diperkuat oleh pernyataan Kepala Sekolah MA Al-Maunah bahwa kebijakan Kurikulum 2013 masih belum diiringi dengan upaya peningkatan kualitas guru dengan pemahaman dan penguasaan yang baik terhadap Kurikulum 2013, dibuktikan dengan para guru di YPI Al-Maunah baik Aliyah maupun Tsanawiyah hampir seluruhnya belum pernah dilibatkan dalam kegiatan Bimtek yang diselenggarakan oleh pemerintah. Hal ini diperkuat dengan penelitian Nurmawati, Natajaya, \& Dantes (2014) yang menyatakan bahwa kesiapan guru Madrasah Aliyah Amlapura masih menghadapi kendalabaik pada aspek konteks, input maupun proses. Kendala pada aspek konteks berupa minimnya pengetahuan dan pemahaman mengenai ciri, asumsi dan implementasi prinsip pengembangan dari Kurikulum 2013. Kendala pada aspek input adalah belum semua guru mampu menyisipkan motivasi, dorongan dan stimulasi siswa dalam pembelajaran. Terakhir, kendala pada aspek proses adalah kesulitan guru dalam menerapkan tahapan proses penilaian yang dianggap cenderung lebih rumit karena diharuskan menyiapkan rubrik penilaian yang sangat menyita waktu. Kendala pelaksanaan juga dirasakan oleh guru-guru MIN 1 Jombang, belum semua guru memiliki kemampuan mengembangkan kegiatan yang mampu memfasilitasi peserta didik mengamati fenomena yang berhubungan dengan materi yang sedang dipelajari (Rouf \& Lufita, 2018).

Munculnya kendala pada madrasah-madrasah di bawah Kementerian Agama salah satunya adalah karena sosialisasi yang dilakukan oleh Kemenag belum optimal dijadikan rujukan dalam mendorong kelancaran pelaksanaan kurikulum, terutama untuk pembelajaran di kelas. Hal tersebut disebabkan sosialisasi yang dilakukan masih bersifat umum mengenai kebijakan dari pelaksanaan kurikulum 2013, tetapi terkait dengan substansi cara pelaksanaan di madrasah belum spesifik dan operasional penjelasannya (Taruna, 2014). Diperparah lagi dengan kenyataan di lapangan yang menunjukkan masih banyak guru madrasah yang bahkan sama sekali belum pernah mengikuti sosialisasi Kurikulum 2013 dikarenakan keterbatasan kuota. Sejalan dengan hasil penelitian Kustijono \& Wiwin HM, (2014) yang mengungkapkan pandangan guru terhadap kurikulum 2013 dilihat dari aspek prinsip pembelajaran, prinsip penilaian, penyusunan RPP, kegiatan pembelajaran dan kegiatan penilaian belum sepenuhnya dapat dipahami dan dituangkan dalam pembelajaran yang guru lakukan di kelas.

Pemahaman yang masih minim terhadap implementasi ideal dari Kurikulum 2013 juga dikarenakan adanya beberapa revisi. Hal ini dinilai sangat wajar karena kurikulum yang baru diterapkan akan terus dilakukan evaluasi dan perbaikanperbaikan sesuai dengan kondisi lapangan. Hanya saja, banyak guru yang kemudian semakin merasa bingung dengan perubahan tersebut. Contoh dari Kurikulum 2013 edisi revisi 2018 adalah Permendikbud Nomor 37 Tahun 2018 dan Permendikbud Nomor 4 Tahun 2018. Permendikbud Nomor 37 Tahun 2018 merupakan perubahan Permendikbud Nomor 24 tahun 2016 mengenai Kompetensi Inti (KI) dan Kompetensi 
Dasar (KD) pelajaran, yang berisikan daftar KI dan KD pelajaran Kurikulum 2013 terbaru, mulai dari tingkat SD/MI, SMP/MTs, sampai SMA/MA (Mendikbud, 2018a). Sedangkan Permendikbud No. 4 Tahun 2018 adalah segenap peraturan dan teknis terkait ketentuan umum, penyelenggaraan, persyaratan peserta didik mengikuti ujian, biaya penyelenggaraan, kelulusan dan sanksi (Mendikbud, 2018b). Penetapan Permendikbud No. 4 Tahun 2018 mencabut aturan sebelumnya yang tertuang pada Permendikbud No. 3 Tahun 2017 dan Permendikbud No. 58 Tahun 2015.

Penelitian mengenai pemahaman guru terhadap Kurikulum Edisi Revisi sudah permah dilakukan oleh Munaris \& Riadi, (2018), namun hanya terkait pemahaman Permendikbud revisi pada Tahun 2016 dengan nomor 20, 21,22, dan 23. Perubahan Kurikulum 2013 edisi revisi 2018 belum ada pengabdian ataupun penelitian yang mengungkap bagaimana pendekatan ataupun pemahaman guru terhadapnya.

Bertitik tolak dari kenyataan sebagaimana tersebut di atas, maka pendampingan dinilai penting untuk dilakukan sebagai wujud pengabdian pada masyarakat sebagaimana yang digulirkan oleh Lembaga Penelitian dan Pengabdian pada Masyarakat (LP2M) IAIN Syekh Nujati Cirebon melalui Tim Pengabdian. Pendampingan ini bertujuan pada upaya pembinaan sehingga para guru dapat mengenal, memahami dan menguasai Kurikulum 2013.

\section{METODE}

Pengabdian dilaksanakan di Yayasan Pondok Pesantren Al Maunah Palimanan Kabupaten Cirebon dengan subjek dampingan adalah guru-guru MA dan MTs AlMaunah yang berjumlah 30. Pengabdian ini menggunakan pendekatan participant active learning, dimana peserta yang terlibat harus mampu berprtisipasi secara aktif dalam kegiatan pelatihan dan pendampingan implementasi kurikulum 2013 edisi revisi 2018 (Fakhriyah, Wanabuliandari, \& Ardianti, 2018). Pelatihan dikemas secara interaktif sehingga terdapat interaksi dua arah yang membuka kesempatan bagi peserta, yang dalam pelatihan ini adalah guru untuk mengutarakan berbagai ide, saran dan pengalaman.

Upaya pelatihan dan pendampingan terkait dengan penerapan kurikulum 2013 bagi guru MTs dan MA di Yayasan Pendidikan Islam Pondok Pesantren Al-Maunah Kecamatan Palimanan Kabupaten Cirebon menggunakan beberapa strategi sebagai berikut.

1) Untuk mengeksplorasi berbagai isu, persoalan, kesulitan, hambatan ataupun lainnya, dikembangkan strategi FGD dilengkapi dengan observasi, wawancara dan dokumentasi. Peneliti mencoba berdialog dan curah pendapat dengan subjek dampingan dalam rangka mencari pokok-pokok penting sebagai bahan kajian dalam pelatihan dan pendampingan penerapan kurikulum 2013.

2) Sebagai follow up dari FGD tersebut, berikutnya adalah melaksanakan kegiatan pendampingan melalui workshop dengan menghadirkan nara sumber yang sesuai dengan materi dan ahli di bidangnya.

3) Pendampingan oleh tim pengabdian mengenai bagaimana berpraktik baik membuat perencanaan pembelajaran, menyusun RPP, melakukan proses pembelajaran, melakukan penilaian dan membuat pelaporan, termasuk melakukan 
peer teaching berdasarkan produk RPP yang telah disusun. Pendekatan individual dilakukan pada saat pendampingan pembuatan RPP. Pendekatan ini memungkinkan subjek pendampingan lebih bisa ditingkatkan keterampilannya selama proses pendampingan (Subaidi \& Nasuka, 2018).

4) Pendampingan real teaching guru-guru MTs dan MA Al-Maunah di kelas melalui observasi oleh tim pengabdian yang dipandu dengan lembar pengamatan praktik pembelajaran. Pendampingan ini dilakukan sebagai bahan diskusi untuk kegiatan pendampingan selanjutnya sebagai upaya perbaikan implementasi kurikulum 2013 yang selama ini sudah dilakukan oleh guru-guru.

Sebagai akhir dari kegiatan pelatihan dan pendampingan adalah evaluasi melalui kegiatan refleksi bersama melalui angket.

\section{HASIL DAN PEMBAHASAN}

Pendampingan mencapai hasil yang diinginkan dengan melalui 5 tahap kegiatan, yaitu, (1) eksplorasi isu subjek dampingan; (2) workshop implementasi kurikulum 2013 edisi revisi 2018; (3) praktik penyusunan RPP dan peer teaching; (4) real teaching di kelas; serta 5) Evaluasi.

\section{Eksplorasi Isu}

Berdasarkan hasil FGD yang dilakukan terhadap para guru dan kepala sekolah baik madrasah Aliyah maupun Tsanawiyah Al-Maunah, mereka menyatakan bahwa salah satu hal penting yang dirasa sangat dibutuhkan bagi para guru di sekolah terkait dengan kegiaan pendidikan dan pengajaran saat ini ialah tentang bagaimana pemahaman dan penguasaan guru terhadap kurikulum 2013 edisi revisi. Salah seorang wakil kepala sekolah MTs Al Maunah yakni Ibu Devi Sarasvaty Ase (34 tahun) menuturkan bahwa:

"Sampai hari ini kami dan guru-guru yang lain di sini belum paham betul tentang Kurikulum 2013. Memang dari istilah, sudah lama kami dengar, kami kenal, dan berusaha mengimplementasikannya tetapi bagaimana implelemntasi yang tepat dalam pembelajaran kami masih kurang memahaminya".

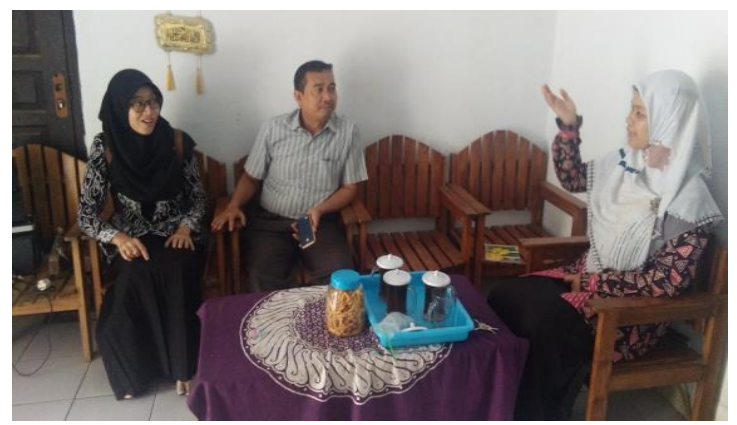

Gambar 1. FGD dengan Wakasek Madrasah Tsanawiyah Al-Maunah Kepuh

Workshop Implementasi Kurikulum 2013 Edisi Revisi 2018

Workshop materi kurikulum 3013 dilakukan untuk memberikan gambaran secara utuh mengenai bagaimana paradigma, aturan baku dan penerapan ideal kurikulum 
2013 kepada para guru. Pelatihan ini diisi oleh 2 narasumber yang kompeten di bidang kurikulum. Narasumber yang pertama adalah Drs. H. Agus Sudjono, M.Pd., beliau merupakan pengawas sekolah senior sekaligus praktisi pendidikan yang sangat sering melakukan pendampingan terkait kurikulum ke sekolah-sekolah. Pelatihan pertama ini lebih menekankan kepada penyempaian tiga hal yang harus dicapai kurikulum 20131, yaitu karakter, literasi dan kompetensi. Narasumber yang kedua adalah pakar pendidikan dari kalangan akademisi perguruan tinggi, yaitu Dr. Muslihudin, M.Pd., yang memiliki kualifikasi pendidikan di bidang kurikulum. Dalam paparan materinya beliau lebih menitikberatkan pada bagaimana impelemntasi kurikulum 2013 pada aspek perencanaan dan pelaksanaan.

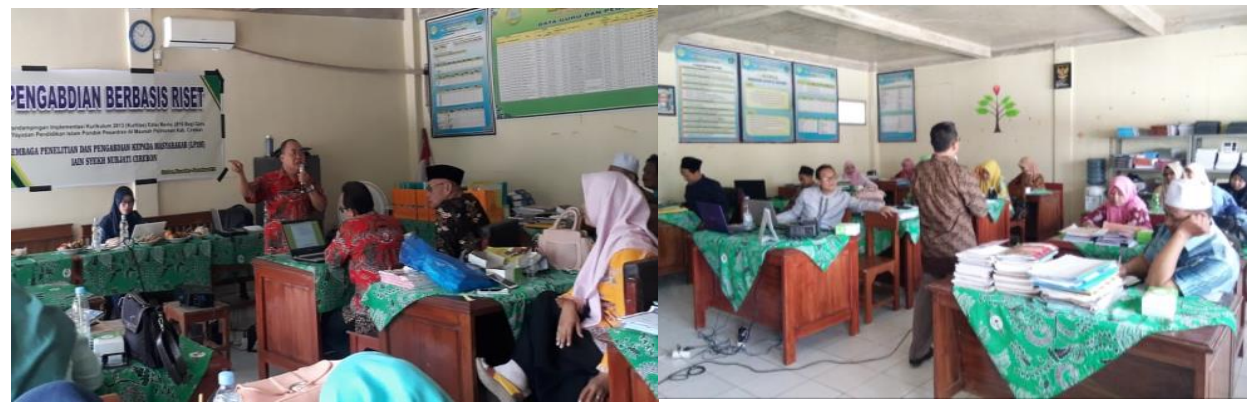

Gambar 2. Workshop Implementasi Kurikulum oleh Pakar Kurikulum

\section{Praktik Penyusunan RPP dan Peer Teaching}

Praktik penyusunan RPP dilakukan baik secara kelompok maupun individu di mana hasilnya dianaliasa dan dikaji bersama. Kegiatan pendampingan dalam penysusnan RPP berjalan sebagaimana visualisasi yang dapat dilihat pada Gambar 3.

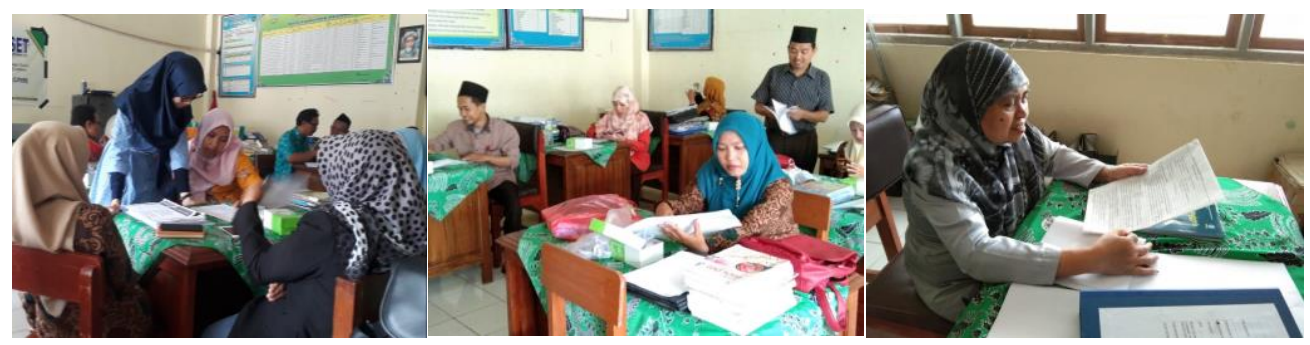

Gambar 3. Praktik Penyusunan RPP secara Berkelompok maupun Individu

Secara prosedural bagaimana komponen-komponen dalam penyusunan RPP mengikuti pedoman sebagaimana yang telah disampaikan oleh narasumber sebelumnya. Salah satu permasalahan yang dirasakan oleh para guru di lapangan sejatinya adalah terjadinya kesimpangsiuran tentang prosedur dan sistematika rencana pelaksanaan pembelajaran. Di antara guru yang satu dengan yang lain saling berbeda pemahaman dalam menangkap bagaimana sistematika dan prosedur penyusunan RPP yang benar. Masing-masing memiliki argument dangan dasar informasi dari sumber yang berbeda. Itu sebabnya pada tataran realitas keberadaan dan impelemntasi kurikulum di lapangan cenderung mengalami dinamika dan relatif terjadi perubahanperubahan. 
Setelah RPP sudah selesai dibuat, kemudian dilakukan peer teaching sesuai perencanaan yang tertuang dalam RPP yang guru buat. Gambaran para guru di MA dan MTs Al Maunah melakukan simulasi praktik mengajar sebagaimana visualisasi berikut pada gambar 4 .

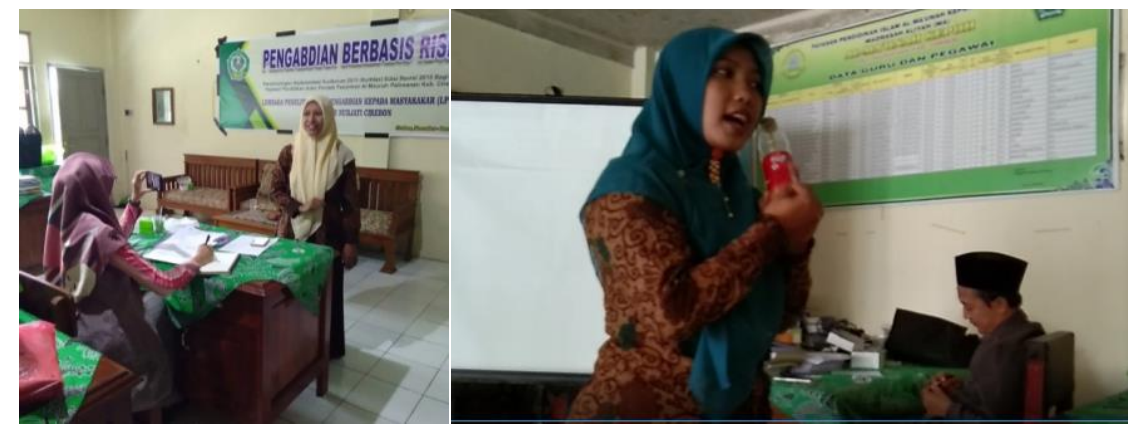

Gambar 4. Peer Teaching sesuai RPP yang dibuat saat Kegiatan Pendampingan

Pendampingan pada tahap ini bertujuan untuk meningkatkan profesionalitas guru-guru di MTs dan MA Al-Maunah. Keberhasilan proses pembelajaran akan terwujud jika ditunjang oleh guru profesional, dimana guru tersebut memiliki kemampuan dimulai dari merancang, memenej, melaksanakan hingga mengevaluasi pembelajaran (Nurmawati et al., 2014).

\section{Real Teaching di Kelas}

Pada tahap ini para guru dari kalangan peserta pendampingan diminta untuk berpraktik mengajar dengan pendekatan saintifik di dalam kelas. Kegiatan ini dilakukan pada tanggal 28 Nopember 2018. Sebagaimana pedoman yang ada bahwa pembelajaran dengan pendekatan saintifik paling tidak meliputi tahapan-tahapan 5M, yaitu mengamati, menalar, menanyakan, mencoba dan mengkomunikasikan. Penampilan yang mereka lakukan dipastikan harus mengacu pada rencana pembelajaran berupa RPP sebagaimana yang telah dibuat. Selama praktik mengajar berlangsung, tim pengabdi melakukan observasi untuk mengamati kesesuaian pembelajaran yang guru lakukan dengan yang dikehendaki oleh kerikulum 2013 edisi revisi.

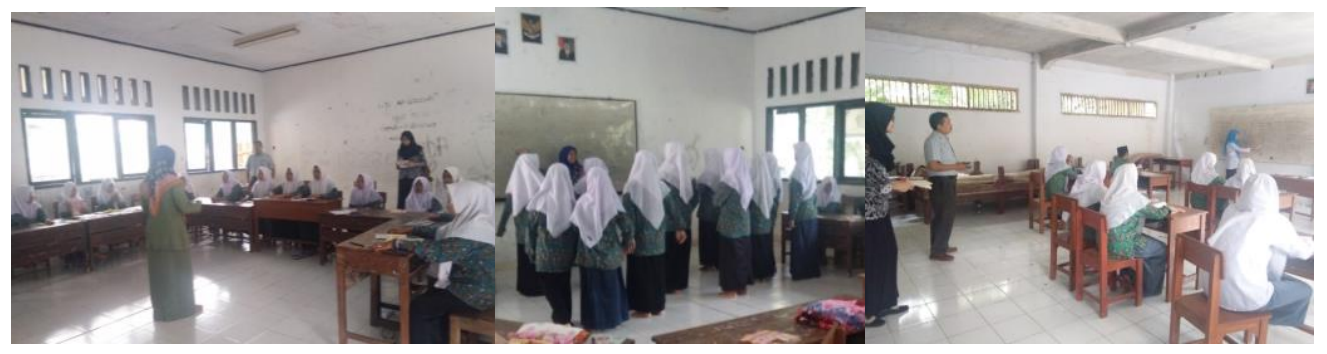

Gambar 5. Pendampingan Real Teaching Subjek Dampingan

Guru sudah seharusnya menjadi fasilitator yang berusaha untuk memanfaatkan ketertarikan siswa secara langsung dalam keseriusan pengalaman belajar, sehingga 
siswa berkembang menjadi manusia dewasa yang mandiri dan mampu beradaptasi pada perubahan pesat dunia global (Prastowo, 2014).

\section{Evaluasi}

Tahap ini merupakan tahap evaluasi dalam bentuk refleksi yang dilakukan terhadap kegiatan simualasi mengajar oleh para guru sebagai bentuk implementasi dari RPP yang telah dibuat dan sekaligus menganalisa hasil real teching yang sudah dilakukan.

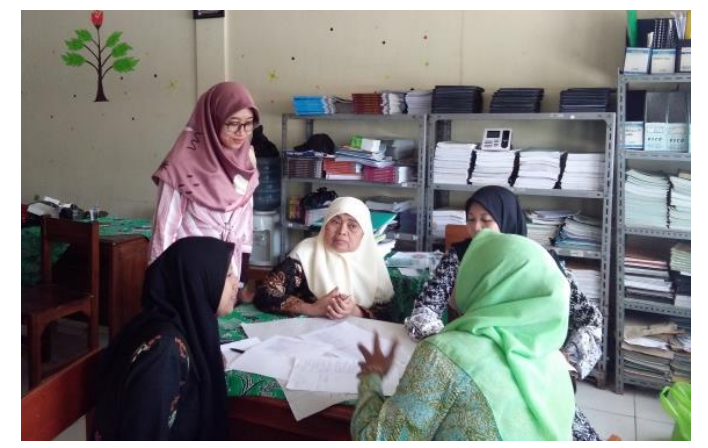

Gambar 6. Diskusi Pembahasan Hasil Real Teaching

Hasil refleksi dari simulasi yang dilakukan tampak bervariasi kualitas tampilan yang guru lakukan. Secara garis besar, guru-guru sudah mampu menuangkan prinsipprinsip Kurikulum 2013 dalam rencana pembelajaran maupun dalm praktik mengajar. Hasil angket terbuka dan video testimoni akan pelatihan Kurikulum 2013 Edisi Revisi seluruhnya menunjukkan respon positif. Berikut salah satulangket terbuka yang telah diisi oleh guru disajikan pada Gambar 7.

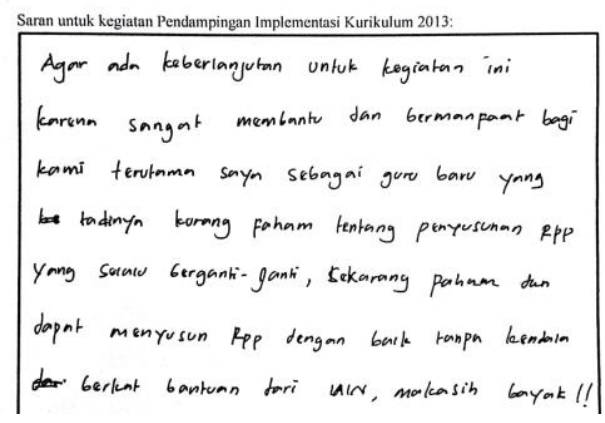

Gambar 7. Angket Terbuka mengenai Respon Guru Terhadap Pelatihan

Berdasarkan upaya pendampingan yang dilakukan terhadap para guru di MA dan MTs Al Maunah Palimanan Kabupaen Cirebon terkait dengan implementasi kurikulum 2013 pada dasarnya didapatkan hasil yang dapat dilihat dari berbagai aspek, yaitu (1) perubahan mindset pada kalangan guru bahwa kronologis dan reasoning digulirkannya kurtilas berorientasi pada upaya mendorong agar dalam pembelajaran terjadi hubungan interaktif, student center, dan kegiatan pembelajaran lebih dominan pada proses; (2) para guru menyadari bahwa cara pembelajaran mereka masih berkutat pada cara-cara pengajaran model lama (konvensional); (3) para guru di MA dan MTs Al 
Maunah mulai paham secara jelas tentang istilah saintifik dengan tahapan-tahapannya meliputi proses mengamati, menalar, menanyakan, mencobakan dan mengkomunikasikan; (4) adanya pendampingan membuat guru semakin menemukan titik terang tentang bagaimana sistematika dan teknik dalam penyusunan rencana pelaksanaan pembelajaran; dan (5) pendampingan impelementasi kurikulum juga banyak memberi wawasan baru dalam berbagai hal bagi guru terkait dengan dunia pendidikan dan pengajaran. Sejalan dengan hasil penelitian Budiani, Sudarmin, \& Syamwil, (2017) bahwa melalui pelatihan dan pendampingan Kurikulum 2013 untuk guru akan didapatkan tiga pengalaman, yaitu (1) pemahaman akan desain dan ide kurikulum; (2) pemahaman mengenai pendekatan penyajian penerapan kurikulum; dan (3) pemahaman dalam penyampaikan konsep kurikulum.

Pada akhirnya, pelaksanaan pelatihan dan pendampingan Kurikulum 2013 edisi revisi memberikan input positif bagisubjek dampingan. Selaras dengan Nurhamidah, Dantes, \& Lasmawan, (2014) yang menegaskan bahwa pendampingan kurikulum 2013 bukan untuk mengevaluasi proses yang sudah dijalankan oleh sekolah, tetapi untuk memperkuat proses berupa penguatan pemahaman guru terhadap konsep maupun implementasi dari Kurikulum 2013 tersebut. Selain melalui pendampingan, pembekalan pemahaman holistik guru mengenai Kurikulum 2013 dapat didapatkan melalui kegiatan lesson study atau forum pertemuan antar sekolah yang sudah menerapkan kurikulum 2013 (Rouf \& Lufita, 2018).

\section{SIMPULAN}

Pelatihan Kurikulum 2013 edisi revisi bagi guru-guru di lingkungan Yayasan Pendidikan Islam Al-Maunah memberikan pemahaman yang lebih holistik mengenai bagaimana prinsip dan implementasi Kurikulum 2013 dalam pembelajaran. Hasil dari tahapan evaluasi berupa refleksi dari semua peserta pelatihan menunjukkan respon positif akan kebermanfaatan pelatihan Kurikulum 2013 edisi revisi dalam meningkatkan profesionalitas sebagai guru.

\section{Ucapan Terimakasih}

Terimakasih kepada IAIN Syekh Nurjati Cirebon yang mensupport kegiatan ini melalui hibah pengabdian berbasis riset dengan SK Rektor Nomor 2698.A/In.08/R/KU.00.1/10/2018.

\section{REFERENSI}

Budiani, S., Sudarmin, \& Syamwil, R. (2017). Evaluasi implementasi kurikulum 2013 di sekolah pelaksana mandiri. Innovative Journal of Curriculum and Educational Technology, 6(1), 45-57. https://doi.org/10.15294/ijcet.v6i1.15998

Fakhriyah, F., Wanabuliandari, S., \& Ardianti, S. D. (2018). Pendampingan publikasi karya ilmiah bagi guru SDN 5 Karangbener Kecamatan Bae, Kudus. Jurnal Pengabdian Pada Masyarakat, 3(1), 93-98. https://doi.org/10.30653/002.201831.44 
Gunawan, I. (2017). Instructional management in Indonesia: a Case study. Researchers World: Journal of Arts, Science and Commerce, 8(1), 99-107. https://doi.org/10.18843/rwjasc/v8i1/12

Kustijono, R., \& Wiwin HM, E. (2014). Pandangan guru terhadap pelaksanaan kurikulum 2013 dalam pembelajaran fisika SMK di Kota Surabaya. Jurnal Penelitian Fisika dan Aplikasinya (JPFA), 4(1), 1-14. https://doi.org/10.26740/jpfa.v4n1.p1-14

Kusumaningrum, D. E., Arifin, I., \& Gunawan, I. (2017). Pendampingan pengembangan perangkat pembelajaran berbasis kurikulum 2013. Abdimas Pedagogi, 1(1), 16-21.

Mendikbud, (2018). Permendikbud RI No. 37 Tahun 2018 tentang Kompetensi Inti dan Kompetensi Dasar Pelajaran Pada Kurikulum 2013 pada Pendidikan Dasar dan Menengah.

Mendikbud, (2018). Permendikbud RI No. 4 Tahun 2018 tentang Penilaian Hasil Belajar oleh Satuan Pendidikan dan Penilaian Hasil Belajar oleh Pemerintah.

Mulyasa, E. (2013). Pengembangan dan Implementasi Kurikulum 2013. Bandung: Remaja Rosdakarya.

Munaris, M., \& Riadi, B. (2018). Pemahaman Guru Bahasa Indonesia SMA di Kabupaten Mesuji terhadap Kurikulum 2013 Edisi Revisi. AKSARA: Jurnal Bahasa Dan Sastra, 19(1), 54-60. https://doi.org/10.23960/aksara/v19i1.pp54-60

Nurhamidah, S., Dantes, N., \& Lasmawan, W. (2014). Upaya peningkatan pengelolaan proses pembelajaran melalui pendampingan pada implementasi kurikulum 2013 terhadap guruguru kelas I dan kelas IV SD di Kecamatan Denpasar Barat. Jurnal Pendidikan Dasar Ganesha, $4(1), 1-11$

Nurmawati, S. D., Natajaya, N., \& Dantes, K. R. (2014). Studi evaluasi kesiapan guru dalam melaksanakan kurikulum 2013 di Madrasah Aliyah Negeri Amlapura tahun 2014. Jurnal Administrasi Pendidikan, 5(1), 1-12.

Prastowo, A. (2014). Paradigma baru madrasah dalam implementasi kebijakan kurikulum 2013. Jurnal Pendidikan Islam, 3(1), 95-113. https://doi.org/10.14421/jpi.2014.31.95-113

Rouf, A., \& Lufita, R. (2018). Peranan guru dalam implementasi kurikulum 2013 di Madrasah Ibtidaiyah Negeri 1 Jombang. Sumbula: Jurnal Studi Keagamaan, Sosial dan Budaya, 3(2), 903926.

Subaidi, \& Nasuka, M. (2018). Pendampingan penulisan karya ilmiah bagi para guru madrasah tsanawiyah. Qardhul Hasan: Media Pengabdian Kepada Masyarakat, 4(2), 112-118. https://doi.org/10.30997/qh.v4i2

Taruna, M. M. (2014). Kesiapan madrasah dalam pelaksanaan kurikulum 2013. Jurnal AtTaqaddum, 6(2), 206-235. https://doi.org/10.21580/at.v6i2.723

Widyasari, W., \& Yaumi, M. (2014). Evaluasi program pendampingan guru sd dalam implementasi kurikulum 2013. Lentera Pendidikan: Jurnal Ilmu Tarbiyah dan Keguruan, 17(2), 281-295. https://doi.org/10.24252/lp.2014v17n2a10

\section{Copyright and License}

This is an open access article distributed under the terms of the Creative Commons Attribution 4.0 International License, which permits unrestricted use, distribution, and reproduction in any medium, provided the original work is properly cited. (C) 2020 Nuryana, Dede Cahyati Sahrir. 